\title{
Identification of follistatin as a possible trait-causing gene in polycystic ovary syndrome
}

\author{
C Asteria \\ Institute of Endocrine Sciences, Ospedale Maggiore IRCCS, University of Milan, Milan, Italy \\ (Correspondence should be addressed to C Asteria; Email: carmela_asteria@yahoo.com)
}

Polycystic ovary syndrome (PCOS) is a common endocrine disorder, which affects up to $5-10 \%$ of women of reproductive age (1). It is characterized by hyperandrogenism and chronic anovulation, which results in reduced fertility (2). The syndrome is also associated with a 7 -fold increased risk for type 2 diabetes mellitus (3).

Familial clustering of cases suggests that genetic factors play an important role in its etiology (4). However, the mode of inheritance of PCOS has not been firmly established. Although studies of families with several cases of PCOS have produced results suggesting an autosomal dominant trait (5-7), others did not (8). There are obvious problems which make genetic studies of PCOS hard to perform $(9,10)$ : (a) heterogeneity and lack of universally acceptable clinical and biochemical criteria for diagnosis of the disorder; (b) difficulty in spanning more than one generation in the segregation studies because PCOS primarily affects premenopausal women; (c) lack of a common acceptable male phenotype; and (d) high prevalence (about $20 \%$ ) of polycystic ovaries in the normal population $(11,12)$. In addition, several pathways are implicated in the etiology of PCOS and, therefore, several candidate genes may be responsible for this 'complex' genetic trait, making the identification of each contributing gene very difficult.

In a recent paper, Urbanek et al. (13) have shown a paradigmatic approach to the genetic study of such a complex disorder, based on the use of appropriately selected standard techniques for linkage analysis, and a good understanding of the physiology and relevant metabolic pathways of gonadal function, these include the regulatory pathways of steroid hormone synthesis (14, 15), gonadotropin action (2), insulin signaling (16-18), and those regulating body weight (19). Thirtyseven genes were chosen from these pathways (Table 1) and examined as candidate genes in 150 families with PCOS (148 of European origin and two of Caribbean origin). The authors performed linkage and association studies, using 'affected-sib pair' (ASP) analysis (20) and the transmission/disequilibrium test (TDT) $(21,22)$, respectively. ASP analysis is a well-known allele-sharing method, the results of which are particularly powerful for specifying a complete genetic model (i.e. identifying each gene that contributes to a disease), as in the case of PCOS. Indeed, allele-sharing methods are nonparametric (that is, assume no model for the inheritance of the trait), ignore unaffected people, and, because they look for alleles or chromosomal segments shared only by affected individuals, are able to test whether affected relatives inherit an identical-by-descent (IBD) region more often than expected under random Mendelian segregation. Thus, using ASP analysis within nuclear families, the presence of a trait-causing gene is revealed by more than the expected $50 \%$ IBD allele sharing. To further support the results obtained by ASP analysis, Urbanek et al. also performed an association study using TDT (13). This method tests whether a particular allele occurs at higher frequency among affected than unaffected individuals, thus involving population correlation rather than cosegregation within a family, as in the case of ASP analysis. TDT represents one of the most advantageous association studies as it is not influenced by population structure or heterogeneity, unlike casecontrol studies.

Several polymorphic markers were tested using genetic analysis in the study of Urbanek et al. (13). Some of these markers were typed within the candidate genes, but for those genes without intragenic polymorphisms, 45 closely linked (within 1-4 centimorgan) short tandem repeats polymorphisms (STRPs) were used. The closer the polymorphism is to the disease gene, the less likely is recombination between the two at meiosis, and therefore the two are more likely to be inherited together.

The clinical study of Urbanek and co-workers was very well designed and the patients were appropriately selected. Previous genetic studies of PCOS have failed to show consistent results, probably because of a difficult phenotype definition $(14,15,23)$. Urbanek and coworkers, however, were able to overcome the problem by selecting a subgroup of patients (index cases and relatives) likely to be more etiologically homogeneous on the basis of the presence or absence of hyperandrogenemia (HA), i.e. elevated levels of total testosterone and testosterone not bound to sex hormone-binding proteins (more than 2 s.D. above the control mean; in their assay the thresholds were $2 \mathrm{nmol} / \mathrm{l}$ and $52 \mathrm{pmol} / \mathrm{l}$ for total and unbound testosterone respectively). This condition was particularly useful for patient selection 
Table 1 Panel of PCOS candidate genes

\begin{tabular}{|c|c|c|}
\hline Pathway & Candidate gene & $\begin{array}{c}\text { Chromosomal } \\
\text { location }\end{array}$ \\
\hline Steroid hormone & $\begin{array}{l}\text { Androgen receptor } \\
\text { CYP11A-cytochrome P450 side-chain cleavage enzyme } \\
\text { CYP17-cytochrome P450 17 } \alpha \text {-hydroxylase/17,20-desmolase } \\
\text { CYP19-cytochrome P450 aromatase } \\
17 \beta \text {-hydroxysteroid dehydrogenase type I } \\
17 \beta \text {-hydroxysteroid dehydrogenase type II } \\
17 \beta \text {-hydroxysteroid dehydrogenase type III } \\
3 \beta \text {-hydroxysteroid dehydrogenase, type I and II } \\
\text { Steroidogenic acute regulatory protein }\end{array}$ & $\begin{array}{l}X q 11.2 \\
15 q 23-24 \\
10 q 24.3 \\
15 q 21 \\
17 q 11-21 \\
16 q 24.2 \\
9 q 22 \\
1 p 31.1 \\
8 p 11.2\end{array}$ \\
\hline Gonadotropin action & $\begin{array}{l}\text { Activin receptor } 1 \\
\text { Activin receptor } 2 \mathrm{~A} \\
\text { Activin receptor } 2 \mathrm{~B} \\
\text { Follistatin } \\
\text { Inhibin A } \\
\text { Inhibin } \beta \text {-A } \\
\text { Inhibin } \beta \text {-B } \\
\text { Inhibin C } \\
\text { Sex hormone binding globulin } \\
\text { Luteinizing hormone/choriongonadotropin receptor } \\
\text { Follicle-stimulating hormone receptor } \\
\text { Mothers against decapentaplegic homolog } 4\end{array}$ & $\begin{array}{l}12 q 13.12 \\
2 q 22.2 \\
3 p 22.2 \\
5 p 14 \\
2 q 33.34 \\
7 p 13-15 \\
2 c e n-2 q 13 \\
12 q 13 \\
17 p 13.2 \\
2 p 21 \\
2 p 21 \\
18 q 21\end{array}$ \\
\hline Obesity and energy regulation & $\begin{array}{l}\text { Melanocortin } 4 \text { receptor } \\
\text { Leptin } \\
\text { Leptin receptor } \\
\text { Pro-opiomelanocortin } \\
\text { Uncoupling protein } 2+3\end{array}$ & $\begin{array}{l}8 q 21.32 \\
7 q 31.3-32.1 \\
1 p 31 \\
2 p 23 \\
11 q 13\end{array}$ \\
\hline Insulin action & $\begin{array}{l}\text { Insulin-like growth factor I } \\
\text { Insulin-like growth factor I receptor } \\
\text { Insulin-like growth factor binding protein } 1+3 \\
\text { Insulin gene VNTR } \\
\text { Insulin receptor } \\
\text { Leydig insulin-like protein } 3 \\
\text { Insulin receptor substrate } 1 \\
\text { Peroxisome proliferator-activated receptor- } \gamma\end{array}$ & $\begin{array}{l}12 q 22-23 \\
15 q 25-26 \\
7 p 13-7 p 12 \\
11 p 15.5 \\
19 p 13.3 \\
19 p 13.1 \\
2 q 36-37 \\
3 p 25-24.2\end{array}$ \\
\hline
\end{tabular}

as it represents the major reproductive endocrine phenotype of PCOS, as demonstrated by previous studies on PCOS families performed by the same group (5).

Among the 37 analysed genes, the authors found promising evidence for linkage with two genes: follistatin and cholesterol side-chain cleavage enzyme (CYP11A). However, only the linkage with follistatin remained significant after correction for multiple testing (multiplying the $P$ value by 33 , the number of regions tested; these regions correspond to 33 distinct chromosomal locations where the 37 genes map). In any case, the evidence for linkage with CYP11A, albeit not significant after correction, confirms, the findings previously published by Gharani et al. (15) and is worthy of further study because multiplying by the full 33 tests probably provides too stringent a correction. The linkage with follistatin was demonstrated by the high IBD levels (72\%) observed for D5S623, the marker closest to follistatin ( $<0.5$ centimorgan), in the affected sib-pairs. However, the TDT did not show evidence of disease association with follistatin. How can this discrepancy be explained? The power to detect association by using a marker depends on several factors: strength of the linkage disequilibrium between marker and disease, the recombination fraction between marker and disease, the increase in risk attributable to the particular susceptibility locus under consideration, and the penetrance of the different disease locus genotypes. It follows that genetic markers may reveal linkage without showing allelic association with the disease, especially if, as in the case of follistatin, the marker is not tightly linked ( $<0.5$ centimorgan).

An important point to discuss is how mutations of follistatin may be responsible for PCOS phenotype. Follistatin is a high-affinity binding protein capable of binding activin and neutralizing its biological activity in vitro and in vivo $(24,25)$. Activin, a member of the transforming growth factor- $\beta$ superfamily, and follistatin are expressed in several tissues, such as ovary, pituitary, adrenal cortex and pancreas. This similar 
pattern of tissue distribution suggests that follistatin is likely to be an auto-/paracrine regulator of the hormonal effects of activin within the tissues. In particular, activin promotes ovarian follicular development, enhances LH binding sites and progesterone production, playing a role in preventing premature luteinization of the ovarian follicles, inhibits thecal cell androgen production, and increases pituitary follicle-stimulating hormone (FSH) secretion and insulin secretion by pancreatic $\beta$-cells. An increase in circulating level or biological activity of follistatin may, therefore, cause follicular development to be arrested, the process of follicular luteinization or atresia to be favored, ovarian androgen production to be increased, FSH circulating levels to be reduced, and insulin release to be impaired. These effects are all characteristic features of PCOS. Moreover, data from transgenic mice overexpressing follistatin seem to confirm these effects (26). Indeed, mice overexpressing follistatin show suppressed serum FSH levels and arrested ovarian folliculogenesis, as observed in patients with PCOS.

In conclusion, the paper by Urbanek et al. (13), by the combination of a well-designed genetic and clinical study, with appropriate clinical classification of the patients, shows how to screen a large number of candidate genes, without testing each gene for mutation, and provides a paradigmatic approach for genetic dissection of complex traits.

\section{References}

1 Dunaif A. Hyperandrogenic anovulation (PCOS): a unique disorder of insulin action associated with an increased risk of non-insulindependent diabetes mellitus. American Journal of Medicine 199598 33S-39S.

2 Franks S. Polycystic ovary syndrome. New England Journal of Medicine $1995333853-861$.

3 Legro RS, Kunselman A, Dodson WC \& Dunaif A. Prevalence and predictors of risk for type 2 diabetes mellitus and impaired glucose tolerance in polycystic ovary syndrome: a prospective, controlled study in 254 affected women. Journal of Clinical Endocrinology and Metabolism 199984 165-169.

4 Legro RS, Spielman R, Urbanek M, Driscoll D, Strauss JF \& Dunaif A. Phenotype and genotype in polycystic ovary syndrome. Recent Progress in Hormone Research 199853 217-256.

5 Carey AH, Chan KI, Short F, Williamson R \& Franks S. Evidence for a single gene effect causing polycystic ovaries and male pattern baldness. Clinical Endocrinology 199338 653-658.

6 Legro RS, Driscoll D, Strauss JF, Fox J \& Dunaif A. Evidence for a genetic basis for hyperandrogenemia in polycystic ovary syndrome. PNAS 199895 14956-14960.

7 Govind A, Obrhai M \& Clayton R. Polycystic ovaries are inherited as an autosomal dominant trait: analysis of 29 polycystic ovary syndrome and 10 control families. Journal of Clinical Endocrinology and Metabolism 199984 38-43.

8 Jahanfar S, Eden JA, Warren P, Seppala M \& Nguyen TV. A twin study of polycystic ovary syndrome. Fertility and Sterility 199563 478-486.
9 Franks S, Gharani N, Waterworth D, Batty A, White D, Williamson $\mathrm{R}$ et al. The genetic basis of polycystic ovary syndrome. Human Reproduction 199712 2641-2648.

10 Legro RS. The genetics of polycystic ovary syndrome. American Journal of Medicine 199598 (Suppl 1A) 9S-16S.

11 Clayton RC, Ogden V, Hodgkinson J, Worswick L, Rodin DA, Dyer S et al. How common are polycystic ovaries in normal women and what is their significance for fertility in general population? Clinical Endocrinology 199237 127-134.

12 Farquhar CM, Birosall M, Manning P, Mitchell JM \& France JT. The prevalence of polycystic ovaries on ultrasound scanning in a population of a randomly selected women. Australian New Zeland Journal of Obstetrics and Gynecology 199434 67-72.

13 Urbanek M, Legro RS, Driscoli DH, Azziz R, Ehrmann DA, Norman RJ et al. Thirty-seven candidate genes for polycystic ovary syndrome: strongest evidence for linkage is with follistatin. PNAS $1999968573-8578$.

14 Carey AH, Waterworth D, Patel K, White D, Little J, Novelli P et al. Polycystic ovaries and premature male pattern baldness are associated with one allele of the steroid metabolism gene CYP17. Human Molecular Genetics 19943 1873-1876.

15 Gharani N, Waterworth DM, Batty S, White D, Gilling-Smith C, Conway GS et al. Association of the steroid synthesis gene CYP11a with polycystic ovary syndrome and hyperandrogenism. Human Molecular Genetics 19976 397-402.

16 Dunaif A, Segal KR, Shelly DR, Green G, Dobrjansky A \& Licholai T. Evidence for distinctive and intrinsic defects in insulin action in polycystic ovary syndrome. Diabetes 199241 1257-1266.

17 Ciraldi TP, el-Roeiy A, Madar Z, Reichart D, Olefsky JM \& Yen SS. Cellular mechanisms of insulin resistance in polycystic ovarian syndrome. Journal of Clinical Endocrinology and Metabolism 1992 75 577-583.

18 Dunaif A, Xia J, Book CB, Schenker E \& Tang Z. Excessive insulin receptor serine phosphorylation in cultured fibroblasts and in skeletal muscle. A potential mechanism for insulin resistance in the polycystic ovary syndrome. Journal of Clinical Investigation $199596801-810$.

19 Kiddy DS, Hamilton-Fairley D, Bush A, Short F, Anayaoku V, Reed MJ et al. Improvement in endocrine and ovarian function during dietary treatment of obese women with polycystic ovary syndrome. Clinical Endocrinology 199236 105-111.

20 Lander ES \& Schork NJ. Genetic dissection of complex traits. Science 1994265 2037-2048.

21 Spielman RS, McGinnis RE \& Ewens WJ. The transmission/ disequilibrium test detects cosegregation and linkage. American Journal of Human Genetics 1994 54 559-560.

22 Ewens WJ \& Spielman RS. The transmission/disequilibrium test: history, subdivision, and admixture. American Journal of Human Genetics 199557 455-464.

23 Waterworth DM, Bennett ST, Gharani N, McCarthy MI, Hague S, Batty $\mathrm{S}$ et al. Linkage and association of insulin gene VNTR regulatory polimorphism with polycystic ovary syndrome. Lancet 1997349 986-990.

24 Mather JO, Moore A \& Li RH. Activins, inhibins, and follistatins: further thoughts on a growing family of regulators. Proceeding Society of Experimental Biological Medicine $1997215209-222$.

25 Sugino H, Sugino K, Hashimoto O, Shoji H \& Nakamura T. Follistatin and its role as an activin-binding protein. Journal of Medicine Investigation 199744 1-14.

26 Guo Q, Kumar TR, Woodruff T, Hadsell LA, DeMayo FJ \& Matzuk MM. Overexpression of mouse follistatin causes reproductive defects in transgenic mice. Molecular Endocrinology 199812 96-106.

Received 9 May 2000

Accepted 10 May 2000 